\title{
Evaluation of Acute Toxicity of Mercury, Cadmium and Zinc to a Freshwater Mussel Lamellidens consobrinus
}

\author{
P.R. Bhamre*, S.P. Thorat, A.E. Desai and B.M. Deoray \\ P.G. Department of Zoolgy, K.T.H.M. College, Nashik- 422 002, Maharashtra, India \\ *E-mail: pramilabhamre@gmail.com
}

Received: 27.03.2010, Accepted: 04.10.2010

\begin{abstract}
Acute toxicity testing of fresh water mussel Lamellidens consobrinus to $\mathrm{HgCl}_{2}, \mathrm{CdCl}_{2}$ and $\mathrm{ZnSO}_{4}$ was carried out. The median lethal concentration $\left(\mathrm{LC}_{50}\right)$ of $\mathrm{HgCl}_{2}, \mathrm{CdCl}_{2}$ and $\mathrm{ZnSO}_{4}$ for 24, 48, 72 and $96 \mathrm{hrs}$ were 1.9616, 1.8602, 1.6983 and 1.4066; 1.9050, $1.8631,1.7542$ and $1.6195 ; 1.9952,1.9664,1.9529$ and $1.6756 \mathrm{ppm}$ respectively. Analysis of results indicates that $L$. consobrinus is highly sensitive to $\mathrm{HgCl}_{2}$ than $\mathrm{CdCl}_{2}$ and $\mathrm{ZnSO}_{4}$. The toxicants can be arranged in order of their toxicities as $\mathrm{Hg}>\mathrm{Cd}>\mathrm{Zn}$.
\end{abstract}

Key words: Lamellidens consobrinus, mercury chloride, cadmium chloride, zinc sulphate, acute toxicity

\section{Introduction}

Indiscriminate use of heavy metal compounds for various purposes and effluents arisen due to their production in water pollution thereby created serious threat to life on the earth. Aquatic pollution is of great concern as every kind of life depends on water.

Heavy metals that reach the aquatic bodies deteriorate the quality of life sustaining water and cause damage to both flora and fauna (Nriagu and Sprague, 1987; Mason, 1996; Kotsanis and Georgudaki, 1999; Zyadah and Abdel Bakey, 2000; Georgudaki and kotsanis, 2001; Verma et al., 2005; Sharma and Agrawal, 2005). Accumulation of toxic metals to hazardous level in the aquatic ecosystem has become a serious problem over the last few decades and it became a threat to public water supplies as well as the damage caused to the aquatic life (Manahann, 1994). The problem increases many folds due to their long half life period and non-biodegradable property, bioaccumulation and biomagnifications (Burman and Lal, 1994; Sandres, 1977; Pitler, 1999; Lodhi et al., 2006).

Cadmium, a nonessential heavy metal has been Black listed in European community (Mason, 1996). It is a nonbiodegradable metal with unknown biological function but reported to be a major contaminant of aquatic ecosystems through diverse sources including both natural and anthropogenic activities. The major sources of contamination includes electroplating, paper, PVC, Plastic, ceramic industries, battery, mining and smoldering units and many other modern industries (Gupta et al., 2003). Zinc is used in preparations of alloys, galvanizing iron, electroplating, metal spraying, electrical phases, batteries and cable wrappings (Merck, 1989). 
Review of literature on water pollution mainly on the river system, includes the use of test animals mainly fish from vertebrates and freshwater mussels from invertebrates. Individual and combined toxicity of mercury and cadmium to tropical green mussel Perna viridis have been reported (Mohan et al., 1986). Comparative toxicity of $\mathrm{Hg}$ and $\mathrm{Cd}$ to the juvenile water snail Filopaludina martensi (Piyatiratitivorakul and Boonchamoi, 2008) and remedial effect of $\mathrm{Ca}^{+}{ }^{+}$on Lead induced alteration in protein and phosphatase activities in gill and mantle of freshwater bivalve Lamellidens marginalis have been reported (Injal and Raut, 2009). The mussels act as a food chain component of the ecosystem and play role in biological control by removing a number of bacterial population and toxic substances from water. The concentration of heavy metals in bivalves changes with respect to the environmental pollution. It has been well established that the study of bioaccumulation of heavy metals in different molluscs facilitates the assessment of water quality as well as the selection of suitable bio-indicator of heavy metal pollution (Chaudhari and Hazra, 2001).

Mercury and its compound is a highly toxic metal but their hazardous nature as pollutant of aquatic environment became a matter of grave concern only after Minamata disaster in Japan. Thus, studies reveals that there is no information on toxicity of Mercury, Cadmium and Zinc to Lamellidens consobrinus, a common bivalve inhabiting in river Darna of Nashik district (M.S.) Hence, present studies were aimed to evaluate comparative toxicity of heavy metals viz., Mercury, Cadmium and Zinc to Lamellidens consobrinus.

\section{Materials and methods}

Mussels L. consobrinus were collected from the river Darna at Nashik road, brought to the laboratory and acclimatized in aged tap water for a period of three days. During acclimatization they were fed with crushed green algae. Pilot experiments were carried out so as to select the final concentrations of heavy metals. Healthy active animals of $L$. consobrinus approximately same size and weight were selected for toxicity testing irrespective of their sex. Three heavy metals viz., $\mathrm{HgCl}_{2}, \mathrm{CdCl}_{2}$ and $\mathrm{ZnSO}_{4}$ were used for toxicity testing. The stock solutions $(1 \%)$ of each toxicant were prepared in distilled water and from which 8-10 concentrations were prepared by diluting the stock solutions so as to set them in the final experiments. Physico-chemical analysis of aged tap water was carried out as per standard methods of APHA (1981). Ten animals were exposed to each concentrations containing five liter toxicant along with control maintained in aged tap water. Three replicates were run for each concentration.

Static bioassays were carried out for a period of 96 hours as per standard methods of APHA (1981). The experimental concentrations were renewed after every 24 hours using aged tap water as diluent medium. During bio-testing, feeding was discontinued. Mortality was recorded after every $24 \mathrm{hrs}$ and data was analyzed so as to compute 24, 48, 72 and 96 hrs $\mathrm{LC}_{50}$ values for three heavy metals by probit analysis (Finney, 1971).

\section{Results}

The physico-chemical analysis of aged tap water showed the temperature $26 \pm 2^{\circ} \mathrm{C}, \mathrm{pH}$ $7.8 \pm 0.2$; total hardness $55 \pm 2 \mathrm{ppm}$ as $\mathrm{CaCo}_{3}$; 
total alkalinity $6.5 \pm 0.3 \mathrm{ppm}$ as $\mathrm{CaCo}_{3}$ and dissolved oxygen $6.5 \pm 0.3 \mathrm{mg} / \mathrm{lit}$.

The $\mathrm{LC}_{50}$ values for different heavy metal pollutants to $L$. consobrinus for 24 , 48, 72 and 96 hrs were calculated. The relative toxicity of heavy metal pollutants, Probit regression equation, $\mathrm{LC}_{50}$ fudicial limits are summarized in table 1 . It is evident from the results (Tab. 1) that the mussel $L$. consobrinus was found to be highly sensitive to $\mathrm{HgCl}_{2}$ than $\mathrm{ZnSO}_{4}$ and $\mathrm{CdCl}_{2}$. The heavy metals can be arranged in order of their toxicities as $\mathrm{Hg}>\mathrm{Zn}>\mathrm{Cd}$.

During the bio-testing, the bivalve showed response to heavy metal treatment. At higher concentration, the test solutions became turbid due to copius secretion of mucus. Another notable effect observed was loss of ability to retract the foot even after mechanical stimulation.

\section{Discussion}

Toxicity studies measure a response of an organism to a biologically active substance (Alderdice, 1966) and are useful in determining water quality. From the result (Tab. 1), it is quite clear that the mussel $L$. consobrinus is highly sensitive to $\mathrm{HgCl}_{2}$ than $\mathrm{CdCl}_{2}$ and $\mathrm{ZnSO}_{4}$. Similar observations have also been reported by various workers using different heavy metals on different test animals (Pundir and Saxena, 1992; Wandkhede and Dhande, 1999; Shrivastava and shrivastava, 2002; Bhamre et al., 1996; Drastichova et al., 2004; Ksherwani et al., 2009). The wide variation in sensitivity of different species to different heavy metals depends on various factors like age, sex, weight, physical stage of the animal and presence or absence of enzyme system that can degrade the pollutants (Nagratnamma and Ramamurti, 1981; Piansiri et al., 2008).
Similar findings were also reported by Georguadaki and Kotsanis (2001).

In the aquatic animals Gills are important organs of respiration. Damage to the gills by different heavy metals and pesticides has been reported by number of workers (Khangarot, 1982; Pawar and Katdare, 1983; Nilkant and Sawant, 1993). It seems therefore anoxia may be an important factor causing death of organisms exposed to pollutants (Skidmore, 1964; Burton et al., 1972).

Another contributing factor causing death may be toxic effect of pollutant on the osmoregulatory mechanism of the animal. It is well known that fish and crustacean gilsl are involved in ionic regulation (Evans, 1975; Hughes and Morgan, 1973) and hence impairment of gill function may affect osmoregulation.

Results of present studies (Tab. 1) clearly indicate that the rate of mortality for any fixed time increases with increase in concentration and for a particular concentration with increase in exposure time and a regular mode of action of toxicant, due to accumulation up to dangerous level leading to death.

The lethal effects of heavy metals $(\mathrm{Hg}, \mathrm{Cu}, \mathrm{Cd}, \mathrm{Zn}$ and $\mathrm{Pb}$ have been described to coagulation of mucus (i.e., precipitation of insoluble metal proteins compounds) on gill surface, damage done to gill tissues and consequently result to the respiratory failure (Dandroff and Katz, 1953).

Thus, from the present studies it can be concluded that the toxicity of tested heavy metals to $L$. consobrinus affect respiratory and nervous system of the animal resulting into death. The present investigations also confirm a high sensitivity of molluse to mercury as compared to $\mathrm{Cd}$ and $\mathrm{Zn}$. 
P.R. Bhamre, S.P. Thorat, A.E. Desai and B.M. Deoray / Our Nature (2010) 8: 180-184

Table 1. Regression equations of probit mortality (y) against $\mathrm{x}$, the logarithm of the metal concentrations, and $\mathrm{LC}_{50}$ values for $L$. consobrinus exposed to $\mathrm{HgCl}_{2}, \mathrm{ZnSO}_{4}$ and $\mathrm{CdCl}_{2}$.

\begin{tabular}{|c|c|c|c|c|c|c|}
\hline \multirow{2}{*}{ SN } & \multirow{2}{*}{ Pollutant } & \multirow{2}{*}{$\begin{array}{c}\text { Exposure } \\
\text { period in Hrs }\end{array}$} & \multirow{2}{*}{$\begin{array}{l}\text { Probit Regression equation } \\
\qquad[\mathbf{y}=\mathbf{a}+\mathbf{b}(\mathbf{x}-\mathbf{m})]\end{array}$} & \multirow{2}{*}{$\begin{array}{c}\mathbf{L C}_{50} \\
\text { in ppm }\end{array}$} & \multicolumn{2}{|c|}{ Fiducial limits } \\
\hline & & & & & $\mathrm{M}_{1}$ & $\mathrm{M}_{2}$ \\
\hline \multirow{4}{*}{1} & \multirow{4}{*}{$\mathrm{HgCl}_{2}$} & 24 & $y=0.41+2.3393(x-0.2925)$ & 1.9616 & 0.1560 & 0.4230 \\
\hline & & 48 & $y=0.94+2.1779(x-0.2699)$ & 1.8602 & 0.1583 & 0.3801 \\
\hline & & 72 & $y=2.02+1.7490(x-0.2302)$ & 1.6983 & 0.1402 & 0.3198 \\
\hline & & 96 & $y=2.17+1.7714(x-0.1480)$ & 1.4066 & 0.0111 & 0.2849 \\
\hline \multirow{4}{*}{2} & \multirow{4}{*}{$\mathrm{ZnSo}_{4}$} & 24 & $\mathrm{y}=0.97+3.1786(\mathrm{x}-0.3000)$ & 1.9952 & 0.1902 & 0.4098 \\
\hline & & 48 & $y=1.59+1.7098(x-0.2936)$ & 1.9664 & 0.1165 & 0.9697 \\
\hline & & 72 & $y=2.46+1.3131(x-0.2860)$ & 1.9329 & 0.0691 & 0.5029 \\
\hline & & 96 & $y=1.69+1.9751(x-0.2799)$ & 1.6756 & 0.1405 & 0.3255 \\
\hline \multirow{4}{*}{3} & \multirow{4}{*}{$\mathrm{CdCl}_{2}$} & 24 & $y=0.01+2.7593(x-0.2799)$ & 1.9050 & 0.1777 & 0.3825 \\
\hline & & 48 & $y=0.98+2.0583(x-0.2702)$ & 1.8631 & 0.2304 & 0.3099 \\
\hline & & 72 & $y=1.53+2.0172(x-0.2440)$ & 1.7542 & 0.1439 & 0.3441 \\
\hline & & 96 & $y=1.99+1.9333(x-0.2094)$ & 1.6195 & 0.1061 & 0.3121 \\
\hline
\end{tabular}

\section{Acknowledgement}

The authors are thankful to the Principal, Dr. V.B. Gaikawad for encouragement and providing laboratory facilities.

\section{References}

Alderdice, D.F. 1966. The detection and measurement of water pollution biological assays. J. Fish. Res. Bd. Can. 25: 1-11.

APHA 1998. Standard methods for the examination of water and waste water, $20^{\text {th }}$ Edn. Washington, D.C

Bhamre, P., V.S. Lomte and K.R. Pawar 1996. Acute toxicity of some selected heavy metals to fresh water bivalve Parreysia favidens. Poll. Res. 15(2): 143-145.

Burman, S.C. and M. Lal 1994. Studied the potential and properties of bioaccumulation of heavy metals $(\mathrm{Zn}, \mathrm{Cu}, \mathrm{Cd}$ and $\mathrm{Pb})$ in soil of industrially polluted fields. J. Environ. Biol. 15: 107-115.

Burton, D.T., A.H. Jones and J.Jr. Cairns 1972. Acute Zinc toxicity to rainbow trout confirmation of hypothesis that death is related to tissue hypoxia. J. Fish. Res. Board can. 29: 14631466.

Chaudhari, A. and Hazra 2001. Trace metal accumulation in 4 different sps. of hetetodont bivalve mollusks. Ind. J. Environ Port. 23: 241-245.

Dandroff, P. and Katz 1953. Critical review of literature on toxicity of industrial wastes and their components to fish. Sewage and industrial Wastes 25: 241-247.

Drastichova, J., Z. Svobodova, V. Luskova and J. Machova 2004. Effect of cadmium on haematological indices of common carp (Cyprinus carpio). Bull. Environ. Contam. Toxicol. 72(4): 725-735.

Evans, D.H. 1975. Ionic exchange mechanism in fish gills. Comp. Bioche. Physiol. 51: 491-495.

Finney, D.J. 1971. Probit Analysis. Cambridge University Press, London.

Georguadaki and N. Kotsanis 2001. Toxic effects of cadmium and mercury in rainbow. Bull. Environ. Contam. Toxicol. 66: 77-85.

Gupta, D.K., U.N. Rai, A. Singh and M. Inouhe 2003. Cadmium accumulation and toxicity in Cicer arietinum L. Poll. Res. 22: 457-463.

Hart, W.B., P. Daudoraff and J. Greenbank 1945. The education of toxicity of industrial wastes, chemicals and other substances to freshwater fish. Waste Control Laboratory, Atlantic Refining Co., Philadelphia 317(14)

Hughes, G.M. and M. Morgan 1973. The structure of fish gill in relation to their respiratory function. Biol. Rev. 48: 419-475. 
P.R. Bhamre, S.P. Thorat, A.E. Desai and B.M. Deoray / Our Nature (2010) 8: 180-184

Injal, A.S. and P.D. Raut 2009. Remedial effect of calcium on lead induced alterations in Proteins and phosphatase activities in the gills and mantle of freshwater bivalve, Lamellidens marginalis. J. Ecophysiol. Occup. Hlth.9: 7784

Kasherwani, D., H.S. Lodhi, K. Tiwari, S. Shukla and U.D. Sharma 2009. Cadmium toxicity to freshwater catfish, Heteropneustes fossils (Bioch.). Asian J. Exp. Sci. 23: 149-156.

Khangarot, B.S. 1982. Histopathological changes in the branchial apparatus of Punctius sopore (Ham.) subjected to toxic doses of Zinc. Arch. Hydrobiol. 93: 352-358.

Kotsanis, N. and J.L. Georgdaki 1999. Arsenic induced liver hyperplasia and kidney fibrosis by microinjection technique: A sensitive animal bioassay for environmental metal toxicity. Bull. Environ. Contam. Toxicol. 62: 169-178.

Lodhi, H.S., M.A. Khan, R.S. Verma and V.D. Sharma 2006. Acute toxicity of copper sulphate to freshwater prawns. J. Environ. Biol. 27(3): 585-588.

Manhann, S.E. 1994. Environmental chemistry. $6^{\text {th }}$ edition, Lewis Publishers, Ann Arbor, London, Tokyo. 812 p.

Mason, C.F. 1996. Biology of freshwater pollution. $3^{\text {rd }}$ edition., Longman, U.K. pp. 1-4.

Merck 1989. The merck index: an encyclopedia of chemicals, drugs and biologicals, $11^{\text {th }}$ Edn., Budavari, (Eds. S.M.J. O'Neil, A. Smith and Heckleman). J. Merck and Ine., New Jersey, U.S.A.

Mohan, C.V., T.R.C. Gupta, H.P.C. Shetty and N.R. Menon 1986. Combined toxicity of mercury and cadmium to the tropical green mussel Perna viridis. Dis. Aquat. Org. 2: 65-72.

Nagratnamma, R. and R. Rammurthi 1981. Comparitive evaluation of methyl parathion toxicity to some selected freshwater organisms. Curr. Sci. 50: 334-335.

Nilkant, G.V. and K.B. Sawant 1993. Studies on accumulation and Histopathology of gills after exposure to sublethal concentration of Hexavalent chromium and effect on the oxygen consumption in Scylla serrata (Forskal). Poll. Res. 12(1): 11-18.

Nriagu, J.O. and J.B. Sprague 1987. Cadmium in the aquatic environment. John Wiley and Sons, Inc. $272 \mathrm{p}$.

Pawar, K.R. and M. Katdare 1983. Acute toxicity of sumithion, BHC and Furadan to some selected freshwater organisms. Biovigyanam 9: 67-72.

Piyatiratitivorakul, P. and P. Boonchamoi 2008. Comparitive toxicity of mercury and cadmium to the juvenile freshwater snail, Filopaludina martensi. Science Asia 34: 367-370.

Pundir and Saxena 1992. Influence of long term exposure to dietary cadmium on growth, maturation and reproduction of gold fish (Subspecies: Prussian carp Carlassius auratus gibelic B.).

Sanders, M.J. 1997. A field evaluation of the freshwater river crab, Potamonautes warren, as a bioaccumulative indicator of metal pollution Thesis, Rand Afrikaans University, South Africa.

Sharma, R.K. and M. Agrawal 2005. Biological effects of heavy metals: An overview. $J$. Environ Biol. 26(2): 301-313.

Shrivastava, R.K. and S. Shrivastava 2002. Cadmium induced haematological changes in a freshwater cat fish, Heteropneustes fossils. $J$. Adv. Zool. 23(1): 23-29.

Skidmore, J.F. 1964. Toxicity of Zinc compounds to aquatic animals with special reference to fish Quart. Rev. Biol. 39: 227-248.

Verma, R.S., M.A. Khan, R. Tripathi, S. Shukla and V.D. Shrama 2005. Heavy metal toxicity to freshwater prawn, Macrobrachium dayanum (Crustacea- Decapoda). Aquaculture 6(1): 5762

Wankhede, G.N. and R.R. Dhande 1999. Effect of cadmium chloride on plasma calcium in the freshwater fish Labeo rohita. J. Ecotoxicol. Environ. Monit. 9(3): 189-192.

Zyadah, M.A. and T.C. Abdel Bakey 2000. Toxicity and bioaccumulation of copper, Zinc and Cadmium in some aquatic organisms. Bull. Environ. Contam. Toxicol. 64: 740-747. 